\title{
Systematic Review and Meta-analysis of Prevalence of
}

\section{Coronary Artery Disease in Adult Patients with Cardiac}

\section{Myxomas [version 1; peer review: 2 approved]}

\author{
Matheus Silva1, Matheus Carneiro², Júlio Nunes², Antônio da Silva², \\ Marcos de Sousa ${ }^{3}$ \\ ${ }^{1}$ Inteventional Cardiology Department, Hospital Universitário Ciências Médicas, Belo Horizonte, 30140-073, Brazil \\ 2Inteventional Cardiology Department, Hospital São José do Avaí, Itaperuna, 28300-000, Brazil \\ ${ }^{3}$ Post Graduation Program in Adult Health Sciences and Division of Cardiology and Cardiovascular Surgery, Hospital das Clínicas, \\ School of Medicine, Universidade Federal de Minas Gerais, Belo Horizonte, Brazil
}

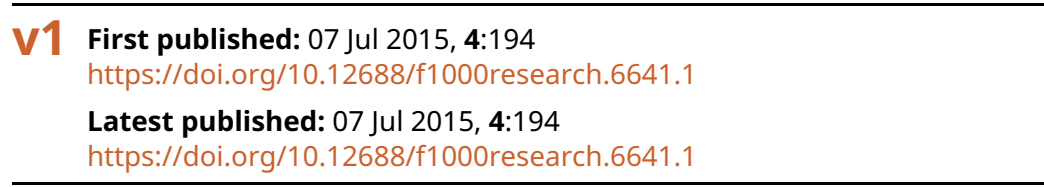

\section{Abstract}

Background: Studies have reported varied prevalence estimates of coronary artery disease (CAD) in cardiac myxoma patients. We performed a systematic review and meta-analysis of observational studies to summarize the point prevalence of CAD in adults with cardiac myxomas.

Methods and Results: Two independent investigators searched MEDLINE and LILACS databases using the terms "Myxoma", "Coronary Angiography" and "Coronary Disease" from inception through December 2014 for all relevant studies. We included 6 observational studies. Publication bias was evaluated through Egger's test and Trim and Fill method. A pooled estimate of CAD prevalence with corresponding 95\% confidence interval (CI) was calculated based on a random-effects model. The pooled CAD prevalence in adult cardiac myxoma patients was $20.7 \%$ with low heterogeneity $\left(\mathrm{I}^{2}=14.86 \%\right)$. Conclusions: It is a matter of debate if preoperative coronary angiography must be done as a routine procedure. Although coronary disease and angiographically detectable neovascularity can alter surgical management, more studies are needed to evaluate this question.

\section{Keywords}

Systematic review, meta-analysis, coronary artery disease , coronary angiography, myxoma

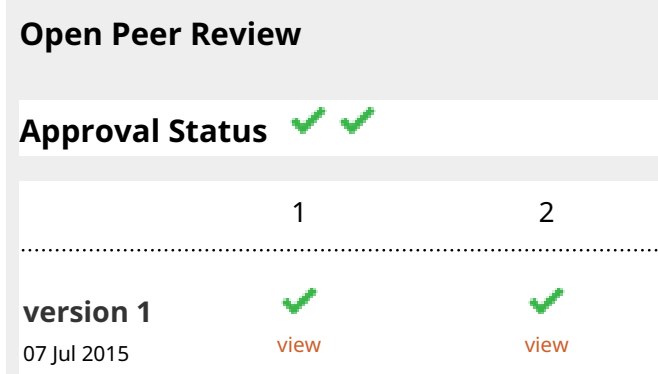

1. Guilherme Costa, University of Manchester, Manchester, UK

\section{Christian Röver (D), University Medical}

Center Göttingen (UMG), Göttingen, Germany

Any reports and responses or comments on the article can be found at the end of the article. 
Corresponding author: Matheus Silva (matheus@me.com)

Competing interests: No competing interests were disclosed.

Grant information: The authors declared that no grants were involved in supporting this work.

Copyright: @ 2015 Silva $\mathrm{M}$ et al. This is an open access article distributed under the terms of the Creative Commons Attribution License, which permits unrestricted use, distribution, and reproduction in any medium, provided the original work is properly cited. Data associated with the article are available under the terms of the Creative Commons Zero "No rights reserved" data waiver (CC0 1.0 Public domain dedication).

How to cite this article: Silva M, Carneiro M, Nunes J et al. Systematic Review and Meta-analysis of Prevalence of Coronary Artery Disease in Adult Patients with Cardiac Myxomas [version 1; peer review: 2 approved] F1000Research 2015, 4:194

https://doi.org/10.12688/f1000research.6641.1

First published: 07 Jul 2015, 4:194 https://doi.org/10.12688/f1000research.6641.1 


\section{Introduction}

Myxomas are the most common primary cardiac tumors, although extremely rare. As an example, in one series of over 12,000 autopsies, only two were identified, for an incidence of less than 0.02 percent ${ }^{1}$. Histologically, these tumors are composed of scattered cells within a mucopolysaccharide stroma. The cells originate from a multipotent mesenchyme that is capable of endothelial and neural differentiation ${ }^{2}$. Myxomas produce vascular endothelial growth factor, which probably induces angiogenesis for tumor growth ${ }^{3}$.

Macroscopically, the tumor surface can be smooth, friable or villous. The tumor diameter varies, ranging from 1 to $15 \mathrm{~cm}$, with a weight typically between 15 and $180 \mathrm{~g}$ (mean, $37 \mathrm{~g}$ ). Friable tumors are more prone to embolization, while larger tumors present with cardiovascular symptoms ${ }^{4}$.

The mean age of patients with myxomas is 56 years and $64-70 \%$ are females. However, myxomas have been described in patients ranging in age from 3 to 84 years. Approximately $86 \%$ of all myxomas occur in the left atrium, and most of the remainder is found in the right atrium. Over $90 \%$ are solitary ${ }^{4,5}$.

The cardiovascular manifestations depend upon the anatomic location of the tumor. In a series of 112 consecutive cases of left atrial myxoma: (1) cardiovascular symptoms were present in $67 \%$, more commonly in the form of mitral valve obstruction (mostly cardiac failure or malaise). Cardiac auscultation abnormalities occurred in $64 \%$, essentially pseudo-mitral valve disease in $53.5 \%$ and more rarely the suggestive tumor plop in $15 \%$. The most frequent electrocardiographic sign was left atrial hypertrophy in 35\%, whereas arrhythmias were uncommon. (2) Embolic symptoms were observed in $29 \%$, essentially cerebral emboli with stroke, with men at greater risk. (3) Constitutional symptoms were observed in $34 \%$ with fever, weight loss, or symptoms resembling connective tissue disease ${ }^{4}$. Right atrial tumors are more commonly associated with signs and symptoms of right heart failure. Tumor fragments can embolize to pulmonary vasculature and cause symptoms consistent with pulmonary emboli, or in the presence of a patent foramen ovale or atrial septal defect, hypoxemia or systemic emboli ${ }^{6,7}$.

Echocardiography is a widely available, simple and noninvasive approach, which in almost all cases precisely locates the tumor and defines its extent. In addition, transesophageal echocardiography (TEE), cardiac magnetic resonance (MRI) and ultrafast computed tomography (CT) have also proved their usefulness in diagnosis ${ }^{8,9}$.

Once a presumptive diagnosis of a cardiac myxoma is made, surgical removal is indicated because of the risk of embolization or of sudden cardiac death. The prognosis for patients with solitary myxomas after surgical resection has been excellent with mortality rates of about $4 \%$. Late recurrences are infrequent and reported to occur in $0.4-5 \%$ of patients ${ }^{10}$.

Several studies have attempted to estimate the rate of cardiac myxomas with concomitant $\mathrm{CAD}$ and we therefore conducted a systematic review and meta-analysis of observational studies to summarize the point prevalence of CAD in adults with these tumors.

\section{Methods}

We carried out a systematic review and meta-analysis of prospective and retrospective observational studies following the PRISMA statement (Supplementary Material S1) ${ }^{11}$. Initially, a search in the main databases (MEDLINE, The Cochrane Library, and LILACS) was performed, searching for studies with similar objectives and methodology. No similar study was found.

A systematic MEDLINE search was performed with the medical subject headings (MeSH) terms ("Myxoma"[MeSH] AND "Coronary Angiography"[MeSH]) OR ("Myxoma”[MeSH] AND "Coronary Disease" $[\mathrm{MeSH}]$ ), looking for trials in English, Spanish and Portuguese, published until December 2014, that performed coronary angiography in patients with cardiac myxomas. At the same time, a systematic LILACS search was also performed using the same $\mathrm{MeSH}$ terms and search strategy.

We designed a relatively strict set of inclusion and exclusion criteria and considered studies meeting these criteria to be of acceptable quality. The study selection criteria were: (1) observational studies, with prospective or retrospective data collection; (2) studies that provided a measure of CAD prevalence in adult patients with cardiac myxomas; (3) studies that included at least five cases of cardiac myxomas; (4) studies in which at least $75 \%$ of the adult cardiac myxoma patients had coronary angiographies; (5) angiographic and demographic data systematically reported.

Two researchers, according to the previously established inclusion criteria, then independently reviewed the titles returned by the systematic search. Exclusion by duplicity, title, abstract and full text analyses was independently performed and discrepancies in each stage were solved by consensus after discussion. The selected articles were read in full to confirm eligibility and their data was tabulated and reviewed for the statistical analysis. The second researcher independently double-checked the extraction of primary data from every study.

The meta-analysis of the pooled prevalence data, as well as associated graphic results was performed using the Comprehensive Meta Analysis software, version 2.2.064. Other computations were performed with IBM SPSS Statistics for Macintosh, Version 22.0.

Heterogeneity of accuracy measures was explored with the $\mathrm{I}^{2}$ estimate (inconsistency measure) from Cochran $Q$ according to the formula: $\mathrm{I}^{2}=100 \% \times($ Cochran $Q-$ degrees of freedom $) /$ Cochran $Q$. This describes the percentage of the variability in effect that is due to heterogeneity rather than sampling error (chance) ${ }^{12}$. Publication bias was graphically assessed using funnel plot, Egger's test and Trim and Fill method ${ }^{13-15}$.

\section{Results}

A flow chart of the studies evaluation is shown in Figure 1. These latter studies were excluded because of a lack of angiographic data in at least $75 \%$ of patients with cardiac myxomas in the populations examined. Thus, a total of 6 studies evaluating the prevalence of $\mathrm{CAD}$ were selected according to the aforementioned criteria. 


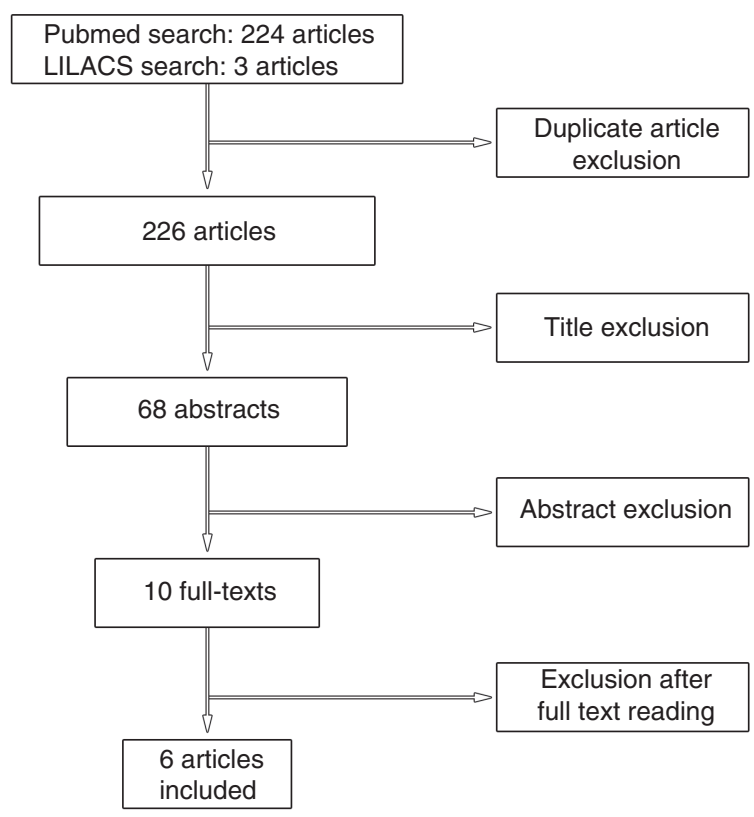

Figure 1. Flowchart of article exclusions by peer review.
For each study, demographic characteristics, the proportion of adult cardiac myxoma patients who underwent coronary angiography and the location of the tumors are listed in Table I. The criteria used to define the presence of CAD and associated treatment when described is listed in Table II. The prevalence rates of clinically confirmed CAD for each of the 6 studies are reported in Figure 2.

As shown, we found an aggregated estimate of $20.7 \%$ (95\% CI 0.12 to 0.32 ). The prevalence rates reported across these studies varied from $5.26 \%{ }^{16}$ to $36.26 \%$ (Figure 2), with low heterogeneity $\left(\mathrm{Q}\right.$-value $=5.873, \mathrm{P}$-value $\left.=0.319, \mathrm{I}^{2}=14.86 \%\right)$. Egger's test (two tailed) was borderline positive for publication bias $(\mathrm{P}=0.047)$. A funnel plot with Trim and Fill method is shown in Figure 3. The close observed and adjusted values of pooled prevalence suggest a small influence of publication bias.

\section{Discussion}

There is little documented literature on the relationship between CAD and cardiac myxomas ${ }^{8}$. This article provides the first compilation of available angiographic data on adult patients with cardiac myxomas and CAD. According to this meta-analysis, the estimated prevalence of CAD in adult patients with myxomas is $20.7 \%$,

Table I. Demographic characteristics of study populations, proportion of patients who underwent CA and location of tumors.

\begin{tabular}{|l|l|l|l|l|}
\hline Study & Male/Female & Mean Age (Years \pm SD) & $\begin{array}{l}\text { Coronary } \\
\text { Angiography }\end{array}$ & $\begin{array}{l}\text { Intracardiac Location } \\
\text { of Myxomas }\end{array}$ \\
\hline Van Cleemput et al. ${ }^{16}$ & $7 / 18$ & $57.37 \pm 9.97$ (range 38-71) & $19 / 25(76 \%)$ & $\begin{array}{l}\text { LA: } 23 \\
\text { RA: } 2\end{array}$ \\
\hline Ergünes et al. ${ }^{17}$ & $8 / 9$ & $54.64 \pm 13.02$ (range 27-75) & $14 / 17(82 \%)$ & $\begin{array}{l}\text { LA: } 14 \\
\text { RA: } 3\end{array}$ \\
\hline Gismondi et al. ${ }^{18}$ & NP & NP & $18 / 21(86 \%)$ & $\begin{array}{l}\text { LA: } 17 \\
\text { RA: } 1\end{array}$ \\
\hline Shapiro et al. ${ }^{19}$ & $3 / 4$ & 56.71 (range 52-65) & $7 / 7(100 \%)$ & LA: 7 \\
\hline Erdil et al. ${ }^{5}$ & $4 / 7$ & 55.72 (range 30-73) & $11 / 11(100 \%)$ & LA: 11 \\
\hline Rahmanian et al. ${ }^{20}$ & $10 / 18$ & $61.3 \pm 13.5$ & $23 / 28(82 \%)$ & LA: 24 \\
\hline
\end{tabular}

Abbreviations: CA, coronary angiography, LA, left atrium; RA, right atrium; NP, not provided.

\section{Table II. Description of CAD patients in each individual study and associated treatment when presented.}

\begin{tabular}{|c|c|}
\hline Study & Description of CAD and Treatment \\
\hline Van Cleemput et al. ${ }^{16}$ & One patient had significant CAD of the LCX, and was considered operable. \\
\hline Ergünes et al..$^{17}$ & One patient was determined to have CAD and was treated with additional CABG. \\
\hline Gismondi et al..$^{18}$ & $\begin{array}{l}\text { Three patients had significant CAD, defined as the existence of } a \geq 50 \% \text { diameter narrowing of the } \\
\text { LMCA or } a \geq 70 \% \text { diameter narrowing of the other coronary arteries. }\end{array}$ \\
\hline Shapiro et al. ${ }^{19}$ & $\begin{array}{l}\text { Two patients had significant coronary obstructions. One patient had a total obstruction of the RCA } \\
\text { and an antecedent myocardial infarction. The second had a severe lesion on the LAD. }\end{array}$ \\
\hline Erdil et al. ${ }^{5}$ & $\begin{array}{l}\text { Four patients had concomitant CAD identified. At surgery CABG was performed after the } \\
\text { resection of left atrial myxoma in three patients. The fourth patient had a noncritical lesion in the } \\
\text { RCA and was treated medically. }\end{array}$ \\
\hline Rahmanian et al.20 & $\begin{array}{l}\text { Six patients had significant CAD, leading to percutaneous angioplasty and stent placement in } \\
\text { three patients, and surgical revascularization during mass excision in the remaining three patients. }\end{array}$ \\
\hline
\end{tabular}

Abbreviations: CAD, coronary artery disease; LCx, left circumflex coronary artery; CABG, coronary artery bypass graft surgery; LMCA, left main coronary artery; RCA, right coronary artery; LAD, left anterior descending coronary artery; LA, left atrium; RA, right atrium; NP, not provided. 


\section{Study name}

Van Cleemput et al.
Ergünes et al.
Gismondi et al.
Shapiro et al.
Rahmanian et al.
Erdil et al.

Statistics for each study

Event Lower Upper

rate limit limit Z-Value P-Value

0.053

0.071

0.167

0.250

0.261

0.364

Summary measure

0.207
0.007

0.010

0.055

0.063

0.122

0.143

0.124
0.294

0.370

0.409

0.623

0.472

0.661

0.323
$-2.813$

$-2.472$

$-2.545$

$-1.346$

$-2.193$

$-0.893$

$-4.340$

0.005
0.013
0.011
0.178
0.028
0.372
0.000

0.013

0.011

0.178

0.372

0.000
Event rate and $95 \% \mathrm{Cl}$

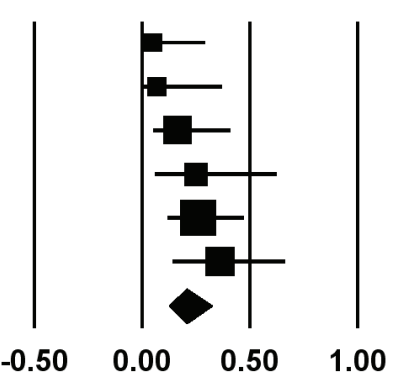

\section{Meta-analysis}

Figure 2. Forest plot of prevalence rate of CAD in adult myxoma patients in 6 studies. Horizontal lines represent $95 \%$ confidence intervals (Cls). Each box represents the prevalence rate point estimate, and its area is proportional to the weight of the study determined by inverse variance weighting. The diamond represents the overall summary estimate, with the $95 \% \mathrm{Cl}$ given by its width.

\section{Funnel Plot of Precision by Logit Event Rate}

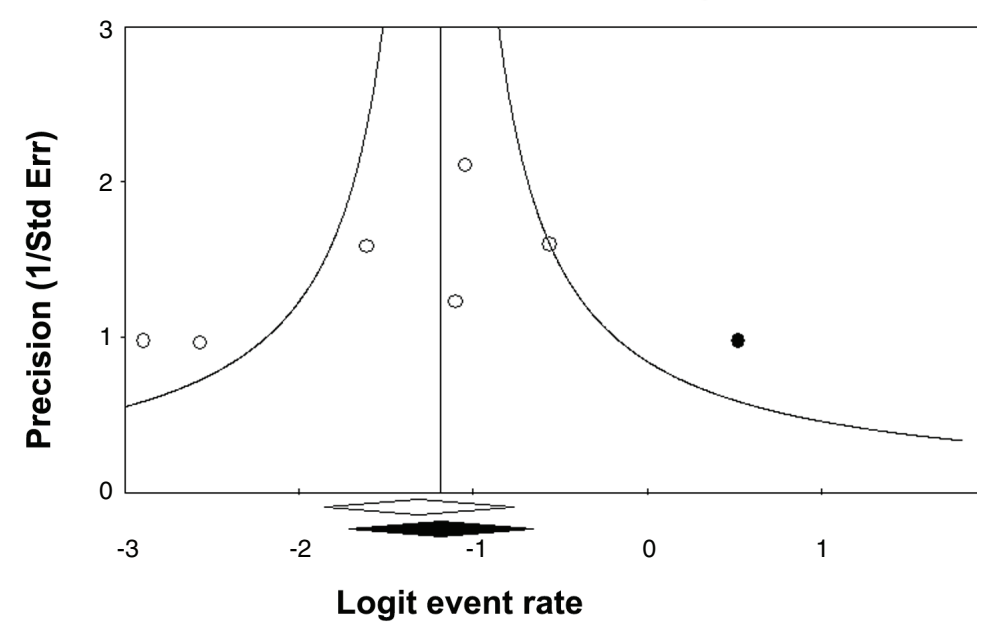

Figure 3. Funnel plot of precision by Logit Event Rate. This is a display of the study's effect size on a logit scale against its precision for each study included in the meta-analysis. Egger's test $\mathrm{P}=0.047$. Trim and Fill method showed close observed $(20.7 \%$ with $95 \% \mathrm{Cl} 12.4$ to $32.3 \%)$ and adjusted (22.7\% with $95 \% \mathrm{Cl} 13.0$ to $36.5 \%)$ values.

with low heterogeneity. In observational studies, Van Cleemput et $a l .{ }^{16}$, Ergünes et al..$^{17}$ and Gismondi et al. ${ }^{18}$ found that CAD prevalence accounted for $5.3 \%, 7.1 \%$ and $16.6 \%$ of adult patients with myxoma, respectively. Shapiro et al. ${ }^{19}$ found a CAD prevalence of $25 \%$ and Erdil et al. ${ }^{5}$ of $36.4 \%$ of adult patients with myxomas. However, in these studies, the number of index patients considered was small, 7 and 11 , respectively. Rahmanian et al. ${ }^{20}$ evaluated 23 out of 28 adult myxoma patients with coronary angiography and found a CAD prevalence of $26.1 \%$; nevertheless, this study enrolled the eldest patients of our series of studies (mean age, 61.3 years).

Concomitant coronary artery bypass grafting (CABG) surgery with resection of the tumor can be crucial in patients with critical coronary lesions. Erdil et al. ${ }^{5}$ identified 4 patients out of 11 with concomitant $\mathrm{CAD}, 3$ of which had adjuvant $\mathrm{CABG}$ performed, and a 
fourth, which had a noncritical lesion in the right coronary artery and was treated medically. Rahmanian et al. ${ }^{20}$ also reported that in 6 out of 23 patients significant CAD was found leading to percutaneous angioplasty and stent placement in 3 patients, and surgical revascularization during mass excision in the remaining three patients. Indeed, out of the 14 patients with CAD identified in the 6 studies included in this meta-analysis, $12(86 \%)$ were subject to, or were liable to invasive treatment.

The use of preoperative coronary angiography (CA) in adult myxoma patients is a topic of debate. Some argue that CA should only be performed in selected patients, particularly those aged $>35-40$ years, with atherosclerotic risk factors, a positive anginal history or with a previous history of myocardial infarction to rule out concomitant coronary artery disease ${ }^{16,20-23}$. However, many report that there has been no significant difference in symptoms, age or prevalence of coronary risk factor distribution between myxoma patients who present with CAD and those who do not ${ }^{5,18,24,25}$. Actually, even patients without any risk factors can present with $\mathrm{CAD}^{25}$. Therefore, others suggest that all adult patients diagnosed with myxomas should undergo $\mathrm{CA}^{5,8,18,25,26}$. In fact, preoperative CA seems to be quite safe; thus far there has been no report of procedure-related complications ${ }^{8,16,18,24-27}$.

Preoperative CA can yield even more information that may prove useful intraoperatively ${ }^{8}$. Selective CA occasionally may visualize the tumor by revealing the angiographic sign of 'tumor vascularity', first described by Marshall et al. ${ }^{28}$, which consists of clusters of small and tortuous vessels with blood pooling and tumor blush arising from the coronary arteries supplying the tumor ${ }^{26,27}$. From the experience of Van Cleemput et al. ${ }^{16}$ and the data published by Fueredi et al..$^{27}$ and Chow et al. ${ }^{26}$, angiographically visible neovascularity is prevalent in around $40 \%$ of symptomatic cardiac myxoma patients. This finding suggests a tumoral origin of the mass, however not specific. Systematic performance of preoperative CA has been recommended by some authors in an attempt to identify a large supplying vessel ${ }^{20}$.

Failure to identify and ligate these vessels may lead to a coronarycavitary fistula ${ }^{29}$ or a "steal syndrome", by re-directing blood from a coronary artery into a cardiac chamber, with consequent myocardial ischemia ${ }^{8}$.

Our study has limitations. As not all patients in each study had performed coronary angiography, the pooled prevalence can be overestimated by verification bias. Patients not selected to perform $\mathrm{CA}$ are probably those with a low risk profile. To overcome this limitation, we decided to not include those studies that reported less than $75 \%$ of patients submitted to CA. Since it is a rare condition, samples are small. Also, number of studies is small. On the other hand, a systematic review is one way to gather evidence on rare conditions. Although the publication bias test was borderline positive, the Trim and Fill method suggested small or no influence of publication bias on pooled results. Even if it is still present, prevalence could be higher, since the adjusted value is slightly higher than the observed value.

\section{Conclusion}

Routine preoperative angiography in all cases of these tumors is still a matter of debate. Pooled prevalence of coronary disease and the potential to disclose angiographically detectable neovascularity are arguments to advocate routine angiography. Patient management and clinical outcomes could be potentially altered, but more studies are needed to answer this question.

\section{Author contributions}

MCS co-conceived the study, participated in the design of the study, search strategy execution, performance of the statistical analysis, and writing the manuscript.

MSC participated in the search strategy execution, performance of the statistical analysis, and writing the manuscript.

JTN participated in the acquisition of data, performance of the statistical analysis, and writing the manuscript.

ACBS participated in the acquisition of data, performance of the statistical analysis, and writing the manuscript.

MRS co-conceived the study, participated in the design of the study, search strategy execution, performance of the statistical analysis, and writing the manuscript.

\section{Competing interests}

No competing interests were disclosed.

\section{Grant information}

The author(s) declared that no grants were involved in supporting this work.
1. Lam KY, Dickens P, Chan AC: Tumors of the heart. A 20-year experience with a review of 12,485 consecutive autopsies. Arch Pathol Lab Med. 1993; 117(10): 1027-31.

PubMed Abstract

2. Pucci A, Gagliardotto P, Zanini C, et al.: Histopathologic and clinical characterization of cardiac myxoma: review of $\mathbf{5 3}$ cases from a single institution. Am Heart J. 2000; 140(1): 134-8.

PubMed Abstract | Publisher Full Text
3. Kono T, Koide N, Hama Y, et al.: Expression of vascular endothelial growth factor and angiogenesis in cardiac myxoma: a study of fifteen patients. Thorac Cardiovasc Surg. 2000; 119(1): 101-7. PubMed Abstract | Publisher Full Text

4. Pinede L, Duhaut $P$, Loire R: Clinical presentation of left atrial cardiac myxoma. A series of 112 consecutive cases. Medicine (Baltimore). 2001; 80(3): 159-72. PubMed Abstract

5. Erdil N, Ates S, Cetin L, et al:: Frequency of left atrial myxoma with concomitant 
coronary artery disease. Surg Today. 2003; 33(5): 328-31. PubMed Abstract | Publisher Full Text

6. Kuon $\mathrm{E}$, Kreplin $\mathrm{M}$, Weiss $\mathrm{W}$, et al.: The challenge presented by right atrial myxoma. Herz. 2004; 29(7): 702-9.

mubMed Abstract | Publisher Full Text

7. Diaz Castro O, Bueno H, Nebreda LA: Acute myocardial infarction caused by paradoxical tumorous embolism as a manifestation of hepatocarcinoma. Heart. 2004; 90(5): e29.

PubMed Abstract | Publisher Full Text | Free Full Text

8. Janas R, Jutley RS, Fenton $\mathrm{P}$, et al:: Should we perform preoperative coronary angiography in all cases of atrial myxomas? Catheter Cardiovasc Interv. 2006; 67(3): 379-83.

PubMed Abstract | Publisher Full Text

9. Vander Salm TJ: Unusual primary tumors of the heart. Semin Thorac Cardiovasc Surg. 2000; 12(2): 89-100.

PubMed Abstract

10. Keeling IM, Oberwalder P, Anelli-Monti M, et al:: Cardiac myxomas: $\mathbf{2 4}$ years of experience in 49 patients. Eur J Cardiothorac Surg. 2002; 22(6): 971-7. PubMed Abstract | Publisher Full Text

11. Liberati A, Altman DG, Tetzlaff J, et al.: The PRISMA statement for reporting systematic reviews and meta-analyses of studies that evaluate healthcare interventions: explanation and elaboration. BMJ. 2009; 339: b2700. PubMed Abstract | Publisher Full Text | Free Full Text

12. Macaskill P, Gatsonis C, Deeks J, et al.: Cochrane Handbook for Systematic Reviews of Diagnostic Test Accuracy. Version 090 London. The Cochrane Collaboration, 2010

Reference Source

13. Sterne JAC, Harbord RM: Funnel plots in meta-analysis. Stata Journal. 2004; 4(2): 127-41.

Reference Source

14. Egger M, Davey Smith G, Schneider M, et al:: Bias in meta-analysis detected by a simple, graphical test. BMJ. 1997; 315(7109): 629-34. PubMed Abstract | Publisher Full Text | Free Full Text

15. Borenstein M, Hedges LV, Higgins JPT, et al.: Introduction to meta-analysis. Chichester, West Sussex, U.K; Hoboken: John Wiley \& Sons. 2009, xxviii. 421p. Publisher Full Text

16. Van Cleemput J, Daenen W, De Geest $\mathrm{H}$ : Coronary angiography in cardiac myxomas: findings in 19 consecutive cases and review of the literature. Cathet Cardiovasc Diagn. 1993; 29(3): 217-20. PubMed Abstract | Publisher Full Text

17. Ergunes $\mathrm{K}$, Yetkin U, Yilik L, et al.: Diagnosis and surgical treatment modalities in cardiac myxomas. Anadolu Kardiyol Derg. 2008; 8(5): 379-80. PubMed Abstract
18. Gismondi RAOC, Martino H, Soares RdC, et al:: Doença arterial coronariana e mixoma cardíaco: prevalência e associação com os fatores de risco convencionais (Coronary artery disease and cardiac myxoma: prevalence and association with conventional risk factors). Rev SOCERJ. 2007; 20(1): 16-9. Reference Source

19. Shapiro JB, Kronzon I, Winer HE: Diagnosis of left atrial tumors by coronary angiography and left ventriculography. Cathet Cardiovasc Diagn. 1979; 5(1): 41-9. PubMed Abstract | Publisher Full Text

20. Rahmanian PB, Castillo JG, Sanz J, et al:: Cardiac myxoma: preoperative diagnosis using a multimodal imaging approach and surgical outcome in a large contemporary series. Interact Cardiovasc Thorac Surg. 2007; 6(4): 479-83. PubMed Abstract | Publisher Full Text

21. Rice PL, Pifarré R: Left atrial myxoma and coronary artery disease: combined surgical treatment. Arch Surg. 1981; 116(3): 353-5. PubMed Abstract | Publisher Full Text

22. Shimono $\mathrm{T}$, Makino $\mathrm{S}$, Kanamori $\mathrm{Y}$, et al.: Left atrial myxomas. Using gross anatomic tumor types to determine clinical features and coronary angiographic findings. Chest. 1995; 107(3): 674-9. PubMed Abstract | Publisher Full Text

23. Sharma S, Sundaram U, Loya Y: Selective coronary angiography in intracardiac tumors. J Interv Cardiol. 1993; 6(2): 125-9.

PubMed Abstract | Publisher Full Text

24. Huang $\mathrm{CY}$, Yu WC, Chen KC, et al:: Coronary angiography of cardiac myxoma Clin Cardiol. 2005; 28(11): 505-9.

PubMed Abstract | Publisher Full Text

25. Li AH, Liau CS, Wu CC, et al:: Role of coronary angiography in myxoma patients: a 14-year experience in one medical center. Cardiology. 1999; 92(4): 232-5.

PubMed Abstract | Publisher Full Text

26. Chow WH, Chow TC, Tai YT, et al.: Angiographic visualization of 'tumour vascularity' in atrial myxoma. Eur Heart J. 1991; 12(1): 79-82. PubMed Abstract

27. Fueredi GA, Knechtges TE, Czarnecki DJ: Coronary angiography in atria myxoma: findings in nine cases. AJR Am J Roentgenol. 1989; 152(4): 737-8. PubMed Abstract | Publisher Full Text

28. Marshall WH Jr, Steiner RM, Wexler L: "Tumor vascularity" in left atrial myxoma demonstrated by selective coronary arteriography. Radiology. 1969; 93(4): 815-6 passim

PubMed Abstract | Publisher Full Text

29. D'Avila AL, Passos LC, Hueb WA, et al.: [Coronary-cavitary fistula after resection of vascularized left atrial myxoma]. Arq Bras Cardiol. 1991; 57(6): $487-8$.

PubMed Abstract 


\section{Open Peer Review}

\section{Current Peer Review Status:}

\section{Version 1}

Reviewer Report 31 May 2017

https://doi.org/10.5256/f1000research.7135.r22954

(C) 2017 Röver C. This is an open access peer review report distributed under the terms of the Creative Commons Attribution License, which permits unrestricted use, distribution, and reproduction in any medium, provided the original work is properly cited.

\section{Christian Röver}

Department of Medical Statistics, University Medical Center Göttingen (UMG), Göttingen, Germany The meta-analysis seems to be performed properly, I only have a few remarks concerning mostly the presentation of results.

Methods section:

1) It would suggest mentioning explicitly here that:

a) a random-effects model was used.

b) the DerSimonian-Laird heterogeneity estimator was used.

c) a logit- (or log-odds-) transformation was used for the effects.

Results section:

2) The forest plot (Fig.2) is somewhat confusing:

a) the $x$-axis should not extend beyond 0 and 1.

b) the p-values (and z-values) shown apparently relate to a test of zero log-odds (i.e. a prevalence of $50 \%$ ), which does not seem to make sense here; these should be dropped.

c) it would be good to also show the numbers of events and totals (CAs and CADs) either here or in one of the tables.

3) I do not see why a selection effect would be plausible, and why one would perform Eggers' test here. Would it be plausible that certain results would not be accessible because they would exhibit 
either a very high or very low CAD prevalence? If not, then the test (and the funnel plot) should probably be omitted.

General minor comments:

4) In order to put the results into context, I would suggest to also hint on the order of magnitude of CAD prevalence in non-myxoma populations, or on potential CAD prevalence thresholds that might warrant consequences.

5) The studies in tables I and II (last two rows) are in a different order than in Fig.2

Are the rationale for, and objectives of, the Systematic Review clearly stated? Yes

Are sufficient details of the methods and analysis provided to allow replication by others? Yes

Is the statistical analysis and its interpretation appropriate?

Partly

Are the conclusions drawn adequately supported by the results presented in the review? Yes

Competing Interests: No competing interests were disclosed.

Reviewer Expertise: Statistics

I confirm that I have read this submission and believe that I have an appropriate level of expertise to confirm that it is of an acceptable scientific standard.

Reviewer Report 24 August 2015

https://doi.org/10.5256/f1000research.7135.r9393

(C) 2015 Costa G. This is an open access peer review report distributed under the terms of the Creative Commons Attribution License, which permits unrestricted use, distribution, and reproduction in any medium, provided the original work is properly cited.

\section{Guilherme Costa}

Cancer Research UK Stem Cell Biology Group, Cancer Research UK Manchester Institute, University of Manchester, Manchester, UK

Definitely an important and clinically relevant topic. Through accurately performed meta-analysis and systematic review, the authors remind us of a rare and usually underrated - though certainly 
morbid - condition which could be managed differently if better researched on.

Are the rationale for, and objectives of, the Systematic Review clearly stated?

Yes

Are sufficient details of the methods and analysis provided to allow replication by others? Yes

Is the statistical analysis and its interpretation appropriate?

Yes

Are the conclusions drawn adequately supported by the results presented in the review? Yes

Competing Interests: No competing interests were disclosed.

I confirm that I have read this submission and believe that I have an appropriate level of expertise to confirm that it is of an acceptable scientific standard.

The benefits of publishing with F1000Research:

- Your article is published within days, with no editorial bias

- You can publish traditional articles, null/negative results, case reports, data notes and more

- The peer review process is transparent and collaborative

- Your article is indexed in PubMed after passing peer review

- Dedicated customer support at every stage

For pre-submission enquiries, contact research@f1000.com 